\title{
VAN DE REDACTIE
}

In het najaar van 1975 werd de derde studieconferentie van de UEC te Belgrado gehouden.

Daarvoor heeft collega Tempelaar een bijdrage geleverd, die wij met toestemming van hem en het conferentiecomité onveranderd in dit nummer plaatsen.

Wij zijn dankbaar voor deze medewerking, waardoor ook in Nederland bekend kan worden wat collega's op buitenlandse congressen brengen. 